Dinitrogen oxide production by a mixed culture of nitrifying bacteria during ammonia shock loading and aeration failure.

Joanna E. Burgess ${ }^{1}$, Bettina B. Colliver, Richard M. Stuetz* and Tom Stephenson.

*Author for correspondence.

School of Water Sciences, Cranfield University, Bedfordshire, MK43 0AL. UK

Tel: $+44(0) 1234754841$

Fax: +44 (0) 1234751671

E-mail: r.stuetz@cranfield.ac.uk

Running title: Dinitrogen oxide production by mixed nitrifying bacteria.

${ }^{1}$ Present address: Dept of Biochemistry, Microbiology and Biotechnology, Rhodes University, Grahamstown, 6140, South Africa. 


\section{Dinitrogen oxide production by a mixed culture of nitrifying bacteria during ammonia shock loading and aeration failure.}

Joanna E. Burgess, Bettina B. Colliver, Richard M. Stuetz and Tom Stephenson

\section{SUMMARY}

A number of experiments was conducted in order to establish if $\mathrm{N}_{2} \mathrm{O}$ in the exhaust gas from activated sludge containing a mixed culture of nitrifiers could be used as a indicator for monitoring the nitrification process. Lab-scale experiments with a chemostat found a strong correlation between ammonia shock loads and both the concentration of $\mathrm{N}_{2} \mathrm{O}$ and the rate of increase of $\mathrm{N}_{2} \mathrm{O}$ in the exhaust gas for shock loads less than $1.6 \mathrm{mg} \mathrm{NH}_{3}-\mathrm{N}^{-1} \mathrm{~g} \mathrm{TSS}^{-1}$. For ammonia shock loads greater that $1.6 \mathrm{mg} \mathrm{NH}_{3}$ $\mathrm{N}^{-1} \mathrm{~g} \mathrm{TSS}^{-1}$ correlation was found between buildup of nitrite in the aeration tank and the concentration of $\mathrm{N}_{2} \mathrm{O}$ in the exhaust gas from the tank. When subjecting the experimental set up to aeration failure a similar pattern was seen with a correlation between nitrite build up in the aeration tank and concentration increase of $\mathrm{N}_{2} \mathrm{O}$ in the exhaust gas. The results from this work suggest the concentration and the changes in the concentration of $\mathrm{N}_{2} \mathrm{O}$ in the exhaust gas from a nitrifying process may be a useful parameter for monitoring such processes.

Keywords: aeration control, dinitrogen oxide, nitrification, nitrous oxide, process monitoring 


\section{INTRODUCTION}

Removal of organic matter together with ammoniacal nitrogen from municipal and industrial wastewater is required by law, prior to discharge [6]. Biological removal of ammonia, nitrification, is traditionally defined as the aerobic oxidation of $\mathrm{NH}_{3}{ }^{+}$to $\mathrm{NO}_{3}{ }^{-}$ via nitrite $\left(\mathrm{NO}_{2}^{-}\right)$. This is mainly carried out by two groups of autotrophic bacteria; ammonia oxidisers $\left(\mathrm{NH}_{3} \mapsto \mathrm{NO}_{2}^{-}\right)$, exemplified by the genera Nitrosococcus and Nitrosomonas, and nitrite oxidisers $\left(\mathrm{NO}_{2}{ }^{-} \mapsto \mathrm{NO}_{3}{ }^{-}\right)$, such as Nitrobacter and Nitrospira spp. $[10,11]$.

The nitrification process is a sensitive process, which can suffer chemical inhibition as well as high ammonia concentrations resulting in decreased or ceased ammonia oxidation $[3,16]$. In the wastewater treatment industry, inhibition of the nitrification process is often seen at works receiving high strength industrial wastewater which can result in the discharged effluent not meeting the required ammonia consents. Monitoring of the nitrification process during wastewater treatment is mainly done by analysing spot tests of the effluent from a process using wet chemistry [1]. This method of monitoring is resource and time consuming and does not allow for early warning of process failure. More recently, some treatments works have experimented with installing biological nitrification toxicity monitors in side streams [9]. This does allow for early warning but such monitors are expensive to install, costly to run, time consuming and often unreliable due to sensor fouling and the need for recalibration [5].

Recently it has been shown that bacteria normally associated with the nitrification process are able to produce nitrogen oxide $(\mathrm{NO})$ and dinitrogen oxide $\left(\mathrm{N}_{2} \mathrm{O}\right)$ under oxic conditions $[13,20]$. These processes have been described as aerobic denitrification. Build-up of $\mathrm{NO}_{2}^{-}$during nitrification is a sign that the nitrification process is failing, as 
$\mathrm{NO}_{2}^{-}$has been shown to be a strong inhibitor of ammonia oxidation through its action on ammonia mono-oxygenase [24], and its accumulation indicates that nitrite oxidisers are also overloaded. A number of studies have shown that the accumulation of $\mathrm{NO}_{2}{ }^{-}$is often seen in nitrifying cultures producing $\mathrm{N}_{2} \mathrm{O}$ and $\mathrm{NO}[12,22,25]$. This suggests that $\mathrm{N}_{2} \mathrm{O}$ in the exhaust gas from a nitrification process could be a useful indicator for monitoring the nitrification process on an industrial scale. Further, Garrido et al. [7] have shown a relationship between $\mathrm{N}_{2} \mathrm{O}$ production and denitrification inhibition in an anoxic filter. The emergence of $\mathrm{N}_{2} \mathrm{O}$ and $\mathrm{NO}_{2}^{-}$in the aeration stage of an activated sludge system should precede the appearance of ammonia in the final effluent by approximately one hydraulic retention time of the entire aeration and clarification system. The aim of this study was to establish if the presence of $\mathrm{N}_{2} \mathrm{O}$ in the exhaust gas from a nitrification process had potential as a way in which to predict and avoid operational failure.

\section{MATERIALS AND METHODS}

\section{Experimental}

A laboratory scale activated sludge pilot plant consisting of a completely mixed aeration tank (7 1) and a settling tank (1 1) was employed (Figure 1). Continuous pH, temperature, and dissolved oxygen (DO) concentrations were monitored using an online computer. The temperature was maintained at $25^{\circ} \mathrm{C}$ by keeping the aeration tank in a heated water bath and DO was maintained at 5.0-5.5 $\mathrm{mg} \mathrm{O}_{2} \mathrm{l}^{-}$by regulating the air flow. A $\mathrm{pH}$ of 7.2 was maintained by means of a feedback from the online computer using sodium bicarbonate $(1.0 \mathrm{M})$ as the buffer. The influent to the activated sludge pilot plant was a synthetic non-nitrified secondary effluent, which was prepared as a solid free 
basal medium feed developed and described in detail by Hanaki et al. [8]. All chemicals used were of AnalarR grade. Glucose of $160 \mathrm{mg} \cdot \mathrm{l}^{-1}$ COD was added as organic matter. Ammonia bicarbonate was the sole source of ammonia and also acted as an alkaline buffer. This gave a steady state nitrogen loading of $244( \pm 15)$ and $184( \pm 12) \mathrm{mg} \mathrm{NH}_{3}$ N.g TSS ${ }^{-1}$. For the shock loading experiments, the ammonia concentration was 701 $( \pm 39) \mathrm{mg} \mathrm{NH} \mathrm{NH} \mathrm{l}^{-1}$, the flow rate of the influent was maintained at $2.25( \pm 0.04) 1 \mathrm{~d}^{-1}$ $(\mathrm{HTR}=3.1$ days $)$ and the solids concentration of the mixed liquor was $1.0( \pm 0.05) \mathrm{mg}$ $\mathrm{TSS}^{-1}$ and the SRT was maintained at 23 days by adjusting the solids recycle rate from the settling tank by adjusting the solids recycle rate from the settling tank. For the aeration failure experiment the ammonia concentration was $1100( \pm 52) \mathrm{mg} \mathrm{NH}_{3}-\mathrm{N}^{-1}$, the flow rate of the influent was maintained at $1.48( \pm 0.03) 1 \mathrm{~d}^{-1}(\mathrm{HTR}=4.7$ days $)$ and

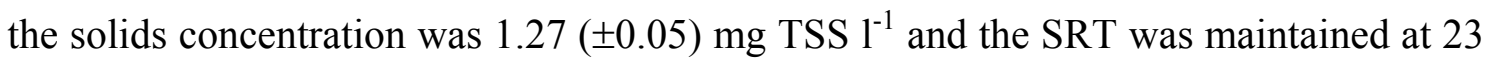
days by adjusting the solids recycle rate from the settling tank.

\section{Inoculation and start-up.}

The nitrifying culture used for inoculation of the aeration tank was kindly provided by Engineered Biological Services (EBS, Berkshire, U.K.). The concentration of nitrifiers in the aeration tank after inoculation was approximately $1.5 \mathrm{~g} \mathrm{TSS}^{-1}$, however, after start-up when the system had reached steady state the concentration of nitrifiers had settled at 1.0 and $1.72 \mathrm{mg} \mathrm{TSS}^{-1}$ for the shock loading experiments and aeration failure experiment respectively. During start-up the initial feed flow rate was approximately $11 \mathrm{~d}^{-1}$. The effluent from the aeration tank was analysed daily for the present of ammonia and nitrite rate. If ammonia or nitrite was present in concentration above $1 \mathrm{mg} \mathrm{l}^{-1}$ the feed flow rate was not increased and effluent was analysed again 24 hours later. If the concentration of ammonia and nitrite was below $1 \mathrm{mg}^{-1}$ the feed flow 
rate was increased by approximately $150 \mathrm{ml} \mathrm{d}^{-1}$. This procedure was repeated until the a flow rate of $2.25( \pm 0.04) 1 \mathrm{~d}^{-1}$ or $1.481 \mathrm{~d}^{-1}$ was reached. It took approximately two weeks to reach steady state. Between each shock loading or oxygen lowering experiment the activated sludge pilot plant was allowed 3-4 days to regain steady state before another was carried out.

\section{Analytical Methods}

Total suspended solids (TSS) of the nitrifying biomass, $\mathrm{NH}_{3}-\mathrm{N}, \mathrm{NO}_{2}^{-}-\mathrm{N}$ and $\mathrm{NO}_{3}^{-}-$ $\mathrm{N}$ was analysed according to standard methods [1]. An infrared gas analyser (VIA-510, Horiba UK, Northampton) fitted with a sampler unit and mist trap (ES-C510SS, Horiba UK, Northampton) was used for online determination of $\mathrm{N}_{2} \mathrm{O}$ concentrations $\left(\mathrm{ppm}_{\mathrm{v}}\right)$ in the exhaust gas from the aeration tank. The $\mathrm{N}_{2} \mathrm{O}$ analyser was calibrated using primary grade nitrogen gas $\left(99.99 \% \mathrm{~N}_{2}\right.$, Air products, UK) for zero calibration and $160 \mathrm{ppm}_{\mathrm{v}}$ $\mathrm{N}_{2} \mathrm{O}$ in nitrogen gas (Air products, UK) for end point calibration. The volume of exhaust gas from the aeration tank was determined by sealing the tank and measure the flow using a bubble flow meter. The total amount of $\mathrm{N}_{2} \mathrm{O}$ in the exhaust gas and the rate of appearance was calculated from the concentration and exhaust data using a spreadsheet.

\section{RESULTS}

In order to determine if the presence of $\mathrm{N}_{2} \mathrm{O}$ in the exhaust gas from a nitrification process could be used as an indicator for monitoring the nitrification process, several experiments were carried out in which the activated sludge plant was either shock loaded with increasing amounts of ammonia $\left(0.53-3.3 \mathrm{mg} \cdot \mathrm{g} \mathrm{TSS}^{-1}\right.$ as $\left.\mathrm{NH}^{3}-\mathrm{N}\right)$ or was 
subjected to aeration failure. The effect of ammonia shock loading and aeration failure on the presence of $\mathrm{N}_{2} \mathrm{O}$ in the exhaust gas was monitored together with build up of ammonia and nitrite in the aeration tank.

\section{Ammonia shock loading.}

The nitrification process was shock loaded by adding 5 to $25 \mathrm{ml}$ of feed directly in the aeration tank of the activated sludge plant running at the conditions stated previously (Figure 1.). This gave a shock loading in the range of $0.53-3.30 \mathrm{mg} . \mathrm{TSS}^{-1}$ as $\mathrm{NH}^{3}-\mathrm{N}$. The air supply was kept constant during an experiment at $1.53( \pm 0.031)$ which gave a start DO of $4.9 \pm 0.3 \mathrm{mg} \mathrm{O}_{2} \mathrm{l}^{-1}$. DO and $\mathrm{pH}$ in the aeration tank was logged once a minute whereas the concentration of $\mathrm{N}_{2} \mathrm{O}$ in the exhaust gas logged every 30 seconds during an experiment. The nitrifying culture in the aeration tank was sampled at 1-4 minutes intervals during an experiment and ammonia, nitrite and nitrate concentrations was determined.

The $\mathrm{pH}$ in the aeration tank was between 7.2-7.5 during all the experiments. Shock loading the nitrifiers with ammonia was always followed by a decrease of DO in the aeration tank and an increase in the concentration of $\mathrm{N}_{2} \mathrm{O}$ in the exhaust gas from the aeration tank (Figure 2). The extent of decrease in the DO and increase in $\mathrm{N}_{2} \mathrm{O}$ was dependant on the size of the shock load, with $\mathrm{N}_{2} \mathrm{O}$ being produced at oxygen concentrations between 1-4 mg $\mathrm{O}_{2} \mathrm{1}^{-1}$. When shock loading the system with $1.6 \mathrm{mg}$ $\mathrm{NH}_{3}-\mathrm{N}$ g $\mathrm{TSS}^{-1}$ (Figure 2) a minimum for the DO and a maximum $\mathrm{N}_{2} \mathrm{O}$ concentration was reached approximately 8 minutes after addition of the shock load, after which the DO started to increase and the $\mathrm{N}_{2} \mathrm{O}$ concentration to decrease. Approximately 40 minutes after applying the shock load both the DO in the aeration tank and $\mathrm{N}_{2} \mathrm{O}$ concentration in the exhaust gas had recovered. 
The obtained data for $\mathrm{N}_{2} \mathrm{O}$ concentrations in the exhaust gas was used to calculate the total amount of $\mathrm{N}_{2} \mathrm{O}$ in the exhaust gas $\left(\mathrm{N}_{2} \mathrm{O}_{\text {TOT }}\right)$, the rate at which $\mathrm{N}_{2} \mathrm{O}$ increased in the exhaust gas $\left(\mathrm{rN}_{2} \mathrm{O}\right)$ and yield of $\mathrm{N}_{2} \mathrm{O}\left(\mathrm{Y}_{\mathrm{N} 2 \mathrm{O}}\right)$ expressed as the percentages of $\mathrm{NH}_{3}-\mathrm{N}$ added during the experiment (via feed and shock load) converted into $\mathrm{N}_{2} \mathrm{O}$ in the exhaust gas (Table 1). In Table 1 the relationship between ammonia shock load and the above calculated parameters is shown together with the maximum concentration of $\mathrm{N}_{2} \mathrm{O}$ $\left(\mathrm{N}_{2} \mathrm{O}_{\text {MAX }}\right)$ determined in the exhaust gas during an experiment. The calculated values for $\mathrm{N}_{2} \mathrm{O}_{\text {TOT }}, \mathrm{rN}_{2} \mathrm{O}, \mathrm{Y}_{\mathrm{N} 2 \mathrm{O}}$, and $\mathrm{N}_{2} \mathrm{O}_{\text {MAX }}$ all increased with increasing level of shock load (Table 1). Correlation analysis showed that strong linear correlation was found between ammonia shock loads up till $1.6 \mathrm{mg} \mathrm{NH}_{3}-\mathrm{N}$ g TSS$^{-1}$ and $\mathrm{N}_{2} \mathrm{O}_{\mathrm{MAX}}\left(\mathrm{r}^{2}=0.98\right), \mathrm{N}_{2} \mathrm{O}_{\text {TOT }}$ $\left(r^{2}=0.96\right)$ and $\mathrm{rN}_{2} \mathrm{O}\left(\mathrm{r}^{2}=0.95\right)$ whereas the $\mathrm{r}^{2}$ for the correlation with $\mathrm{Y}_{\mathrm{N} 2 \mathrm{O}}$ was only 0.87. Figure 3 shows the change of $\mathrm{N}_{2} \mathrm{O}_{\mathrm{MAX}}$ and $\mathrm{rN}_{2} \mathrm{O}$ with increasing ammonia shock loads. The increases in $\mathrm{rN}_{2} \mathrm{O}$ and $\mathrm{N}_{2} \mathrm{O}_{\text {MAX }}$ were linear for ammonia shock loads until $1.6 \mathrm{mg}$ $\mathrm{NH}_{3}-\mathrm{N} \mathrm{g} \mathrm{TSS}{ }^{-1}$ after which the relationship appears to reach saturation.

Accumulation of nitrite was observed for shock loads above $1.03 \mathrm{mg} \mathrm{NH}_{3}-\mathrm{N} \mathrm{g}$ $\mathrm{TSS}^{-1}$, with the amount increasing for increasing shock load. Figure 4 shows the concentration of $\mathrm{N}_{2} \mathrm{O}$ in the exhaust gas and nitrite in the aeration tank after shock loading with 1.6 and $3.3 \mathrm{mg} \mathrm{NH}-\mathrm{N} \mathrm{g} \mathrm{TSS}{ }^{-1}$. At high levels of shock loading, at which $\mathrm{rN}_{2} \mathrm{O}$ and $\mathrm{N}_{2} \mathrm{O}_{\text {MAX }}$ had reach saturation, the accumulation of nitrite followed a similar profile to the concentration of $\mathrm{N}_{2} \mathrm{O}$ in the exhaust gas $\left(\mathrm{r}^{2}=0.86\right)$, and the maximum concentration of nitrite determined in the aeration tank was $2.5 \mathrm{mg} \mathrm{NO}{ }_{2}^{-}-\mathrm{N} \mathrm{l}^{-1}$. By contrast, at shock loads less than $1.6 \mathrm{mg} \mathrm{NH}_{3}-\mathrm{N} \mathrm{g} \mathrm{TSS}^{-1}$ only small amounts of nitrite accumulated $\left(>0.6 \mathrm{mg} \mathrm{NO}_{2}^{-}-\mathrm{N}^{-1}\right)$. 


\section{Aeration failure}

The aeration of the nitrifying activated sludge pilot plant was lowered from 3.7 to $0.31 \mathrm{~min}^{-1}$ and the concentration of $\mathrm{NO}_{2}^{-}$and $\mathrm{DO}$ in the aeration tank and $\mathrm{N}_{2} \mathrm{O}$ in the exhaust gas was recorded. $\mathrm{DO}$ and $\mathrm{pH}$ in the aeration tank were logged once a minute and the concentration of $\mathrm{N}_{2} \mathrm{O}$ in the exhaust gas was logged every 30 seconds during an experiment. The nitrifying culture in the aeration tank was sampled at 1-4 minutes intervals during an experiment and ammonia, nitrite and nitrate concentrations were determined.

Figure 5a shows the decrease in DO concentration in the aeration tank after turning down the aeration. When the DO reached a concentration of less than $1 \mathrm{mg} \mathrm{O}_{2} \mathrm{l}^{-}$ ${ }^{1}, \mathrm{~N}_{2} \mathrm{O}$ started to appear in the exhaust gas and $\mathrm{NO}_{2}^{-}$started to accumulate in the aeration tank. It can be observed that the profile for $\mathrm{NO}_{2}{ }^{-}$accumulation in the aeration tank follows the profile for $\mathrm{N}_{2} \mathrm{O}$ concentration in the exhaust gas, with the concentration increasing with time. Correlation analysis again showed that a strong linear correlation was found between the concentration increase of $\mathrm{NO}_{2}^{-}$in the aeration tank and $\mathrm{N}_{2} \mathrm{O}$ in the exhaust gas $\left(r^{2}=0.99\right)$. After 53 minutes the aeration was returned to $3.71 \mathrm{~min}^{-1}$ (Figure 5b). After the aeration was increased, the concentration of $\mathrm{N}_{2} \mathrm{O}$ in the exhaust gas decreased rapidly, whereas it took another 20 minutes for the concentration of $\mathrm{NO}_{2}^{-}$ in the aeration tank to decrease. At the same time the DO concentration started to increase, however, a small decrease was observed between $65-72$ minutes where the $\mathrm{NO}_{2}{ }^{-}$concentration reached its maximum (Figure $5 \mathrm{~b}$ ). After approximately 90 minutes from the start of the experiment the DO, $\mathrm{N}_{2} \mathrm{O}$ and $\mathrm{NO}_{2}{ }^{-}$concentration had recovered to pre-experimental values. 


\section{DISCUSSION}

A laboratory scale activated sludge plant inoculated with a mixed culture of nitrifying bacteria was used to study the production of $\mathrm{N}_{2} \mathrm{O}$ during ammonia shock loading and aeration failure. The results from the ammonia shock loading experiment showed that $\mathrm{N}_{2} \mathrm{O}$ was produced during shock loading with ammonia at oxygen concentrations as high as $4 \mathrm{mg} \mathrm{O}_{2} \mathrm{l}^{-1}$. Both the rate at which the $\mathrm{N}_{2} \mathrm{O}$ concentration increased in the exhaust gas and the maximum concentration observed in the exhaust gas were found to correlate to the size of the ammonia shock load (for ammonia shock loads less than 1.6 $\mathrm{mg} \mathrm{NH}-\mathrm{N} \mathrm{g} \mathrm{TSS}{ }^{-1}$ ). However, with ammonia shock loads greater than $1.6 \mathrm{mg} \mathrm{NH} \mathrm{NH}_{3}-\mathrm{Ng}$ $\mathrm{TSS}^{-1}$, both the maximum and the rate of increase of $\mathrm{N}_{2} \mathrm{O}$ in the exhaust gas appeared to reach saturation, which indicated that the $\mathrm{N}_{2} \mathrm{O}$ production by the nitrifiers had reached its maximum. This may have been due either to DO reaching zero or to the oxidation rate of the ammonia reaching its maximum at this concentration. Similar results were reported by Nogita et al. [15] and Satio et al. [21], who found that the rate of $\mathrm{N}_{2} \mathrm{O}$ production by activated sludge receiving municipal wastewater was related to both the COD and nitrogen loading. However, they did not observe the rates reaching a maximum.

Previous authors have reported that ammonia-oxidising bacteria under both oxygen-limiting and oxygen-free conditions reduce $\mathrm{NO}_{2}^{-}$formed from ammonia oxidation to $\mathrm{N}_{2} \mathrm{O}$ and further to $\mathrm{N}_{2}$ [22]. The increase in $\mathrm{N}_{2} \mathrm{O}$ is an effect of the decrease in DO causing the bacteria to use $\mathrm{NO}_{2}^{-}$as the terminal electron acceptor. Other studies have shown that the principal mechanisms for $\mathrm{N}_{2} \mathrm{O}$ production by ammonia oxidisers is simultaneous reduction of ammonia and oxidation of nitrite, also causing nitrite to be used as the terminal electron acceptor instead of oxygen $[2,4,18,19]$. The large 
amounts of nitrite accumulated when shock loads were above $1.6 \mathrm{mg} \mathrm{NH} \mathrm{NH}_{3}-\mathrm{N}$ TSS${ }^{-1}$, (Figure $4 \mathrm{a}, \mathrm{b}$ ) could be explained by the fact that the rate at which $\mathrm{N}_{2} \mathrm{O}$ increased in the exhaust gas had reached its maximum and nitrite was produced in excess. However, it could also be due to the nitrite oxidising bacteria not being able to oxidise the produced nitrite fast enough, due to lack of oxygen. Studies by Laanbroek and Gerards [14] have suggested that the ability of ammonia oxidisers to substitute oxygen with nitrite as the terminal electron acceptor at low oxygen concentrations gives them a competitive edge over nitrite oxidisers at low oxygen concentrations

The response to aeration failure (oxygen lowering experiment) was similar to that of high level shock loading, with decreasing DO in the aeration tank and simultaneous increases in $\mathrm{N}_{2} \mathrm{O}$ concentration in the exhaust gas and increased nitrite in the aeration tank (Figure 5a). However during this experiment the presence of $\mathrm{N}_{2} \mathrm{O}$ first occurred at DO concentrations under $1 \mathrm{mg} \mathrm{O}_{2} \mathrm{l}^{-1}$.

\section{CONCLUSIONS}

Two sets of experiments were conducted on a laboratory scale activated sludge pilot plant inoculated with a mixed nitrifying bacterial culture and fed a synthetic nonnitrified secondary effluent in order to determine whether $\mathrm{N}_{2} \mathrm{O}$ detected in the exhaust gas could be used for monitoring the nitrification process. During one set of experiments the effect of ammonia shock loading and was investigated and the following was found: 
- The concentration of $\mathrm{N}_{2} \mathrm{O}$ in the exhaust gas from the nitrifying activated sludge pilot plant and the rate at which it increases were correlated to the size of the ammonia shock load for shock loads less than $1.6 \mathrm{mg} \mathrm{NH}_{3}-\mathrm{N} \mathrm{g} \mathrm{TSS}^{-1}$.

- For ammonia shock loads greater than $1.6 \mathrm{mg} \mathrm{NH}_{3}-\mathrm{N} \mathrm{g} \mathrm{TSS}^{-1}$, the concentration of $\mathrm{N}_{2} \mathrm{O}$ in the exhaust gas was related to the build-up of nitrite in the aeration tank

- During aeration failure the increase of $\mathrm{N}_{2} \mathrm{O}$ in the exhaust gas was closely related to the build up of nitrite in the aeration tank.

From this study it can be concluded that both the concentration and the rate of increase of $\mathrm{N}_{2} \mathrm{O}$ may be good indicators for monitoring the nitrification process, as they are correlated to both ammonia shock load and the build-up of nitrite in the aeration tank. If the emergence of $\mathrm{N}_{2} \mathrm{O}$ in the exhaust gas of the first stage of a nitrification process precedes the appearance of ammonia in the final effluent by approximately one hydraulic retention time, as expected, these results illustrate the potential of monitoring $\mathrm{N}_{2} \mathrm{O}$ for predicting operational failure and providing an opportunity to take remedial action. Further work in which the impacts of ammonia shock loads, aeration reduction and toxic shocks on the nitrogen balance of a two-stage activated sludge system should be carried out and the time frame available for remedial action after an $\mathrm{N}_{2} \mathrm{O}$ increase is recorded should be determined.

\section{ACKNOWLEDGEMENTS}

The authors would like to thank the UK Engineering and Physical Sciences Research Council for financial support of this work. 


\section{REFERENCES}

1. APHA (1998). Standard Methods for the Examination of Water and Wastewater 20th edn, American Public Health Association / American Water Works Association / Water Environment Federation, Washington DC.

2. Anderson IC, M Poth, J Homstead and D Burdige. 1993. A comparison of NO and $\mathrm{N}_{2} \mathrm{O}$ production by the autotrophic nitrifier Nitrosomonas europaea and the heterotrophic nitrifier Alcaligenes faecalis. Appl. Environ Microbiol. 59: 3525-3533.

3. Anthonisen AC, RC Loehr, TBS Prakasam and EG Srinath. 1976. Inhibition of nitrification by ammonia and nitrous acid. J. Wat. Pollut. Cont. Fed. 48(5): 835-852.

4. Bock E, I Schmidt, R Stuven and D Zart. 1995. Nitrogen loss caused by nitrifying Nitrosomonas cells using ammonia or hydrogen as electron donors and nitrite as electron acceptor. Arch. Microbiol. 163: 16-20.

5. Bourgeois W, JE Burgess and RM Stuetz. 2001. On-line monitoring of wastewater quality: a review. J Chem Tech Biotech. 76(4): 337-348.

6. EEC L135 (1992). Council Directive of 21 May 1991 concerning urban waste water treatment. Official Journal of the European Communities, 34: L 135.

7. Garrido JM, J Moreno, R Méndez-Pampín and JM Lama. 1998. Nitrous oxide production under toxic conditions in a denitrifying anoxic filter. Wat. Res. 32: 25502552.

8. Hanaki K, C Wantawin and S Ohgaki. 1990. Nitrification at low levels of dissolved oxygen with and without organic loading in a suspended-growth reactor. Wat. Res. 24: 297-302.

9. Hayes E, J Upton, R Batts and S Pickin. 1998. On-line nitrification inhibition monitoring using immobilised bacteria. Wat. Sci. Tech. 37: 193-196.

10. Hovanec TA and DeLong EF. 1996. Comparative Analysis of Nitrifying Bacteria Associated with Freshwater and Marine Aquaria. App Env Microbiol 62:2888-2896

11. Juretschko S, Timmermann G, Schmid M, Schleifer K-H, Pommerening-Roser A, Koops H-P and Wagner M. 1998. Combined molecular and conventional analyses of nitrifying bacterium diversity in activated sludge: Nitrosococcus mobilis and Nitrospira-like bacteria as dominant populations. App Env Microbiol 64:3042-3051. 
12. Kester RA, W de Boer and HJ Laanbroke. 1997. Production of $\mathrm{NO}$ and $\mathrm{N}_{2} \mathrm{O}$ by pure cultures of nitrifying and denitrifying bacteria during changes in aeration. Appl. Environ. Microbiol. 63: 3872-3877.

13. Kuenen JG and A Robertson. 1994. Combined nitrification and denitrification processes. FEMS Microbiol. Rev., 15: 109-117.

14. Laanbroek H. and S Gerards. 1993. Competition for limiting amounts of oxygen between Nitrosomonas europaea and Nitrobacter winogradskyi grown in mixed continuous cultures. Arch Microbiol. 159: 453-459.

15. Nogita S, Y Saito, and T Kuge. 1991. A new indicator of the activated sludge process- nitrous oxide. Wat. Sci. Tech. 13: 199-204.

16. Painter HA. 1985. Nitrification in the treatment of sewage and wastewaters. 1986. In: Nitrification (Prosser JI, ed), pp 185-211, Spec. Pub. Soc. Gen. Microbiol. Vol. 20, Academic Press.

17. Prosser JI. 1989. Autotrophic nitrification in bacteria. Adv. Microbiol. Physiol. 30: 125-181.

18. Poth $\mathrm{M}$ and DD Focht. 1985. $15^{\mathrm{N}}$ kinetic analysis of $\mathrm{N}_{2} \mathrm{O}$ production by Nitrosomonas europaea: an examination of nitrifier denitrification. Appl Environ. Microbiol. 49: 1134-1141.

19. Ritchie GAF and DJJ Nicholas. 1972. Identification of the source of Nitrous Oxide produced by oxidative and reductive processes in Nitrosomonas europaea. Biochem. J. 126: 1181-1191.

20. Roberston LA and JG Keunen. 1984. Aerobic denitrification: a controversy revived. Arch. Microbiol. 139: 351-354.

21. Satio Y, S Nigota, S Watanabe and K Baba. 1994 Process for controlling an aeration tank in an activated sludge sewage treatment. United States Patent. 4,437,992.

22. van Schulthess $R$ and $W$ Gujer. 1996. Release of nitrous oxide $\left(\mathrm{N}_{2} \mathrm{O}\right)$ from denitrifiying activated sludge: verification and application of a mathematical model. Wat. Res. 30: 521-530.

23. Shrestha NK, Hadano S, Kamachi T and Okura I. 2001. Conversion of ammonia to dinitrogen in wastewater by Nitrosomonas europaea. Appl. Biochem. Biotech. 90: 221232.

24. Stein LY and DJ Arp. 1998. Loss of ammonia mono-oxygenase activity in Nitrosomonas europaea upon exposure to nitrite. Appl. Environ. Microbiol. 64: 40984102.

25. Sümer E, A Weiske, G Benckiser, and JCG Ottow. 1995. Influence of environmental conditions on the amount of $\mathrm{N}_{2} \mathrm{O}$ released from activated sludge in a domestic waste water treatment plant. Experientia 51: 419-422. 
Table 1. Dinitrogen oxide production by a mixed culture of nitrifiers when shock loaded with ammonia.

\begin{tabular}{|c|c|c|c|c|}
\hline $\begin{array}{c}\text { Ammonia load } \\
\left(\mathrm{mg} \mathrm{NH}_{3}-\mathrm{N} . \mathrm{g} \mathrm{TSS}^{-1}\right)\end{array}$ & $\begin{array}{c}\mathrm{N}_{2} \mathrm{O}_{\mathrm{MAX}}{ }^{\mathrm{a}} \\
\left(\mu \mathrm{g} \mathrm{N}_{2} \mathrm{O}-\mathrm{N}^{-1}\right)\end{array}$ & $\begin{array}{c}\mathrm{N}_{2} \mathrm{O}_{\mathrm{TOT}}^{\mathrm{b}} \\
\left(\mu \mathrm{g} \mathrm{N}_{2} \mathrm{O}-\mathrm{N}\right)\end{array}$ & $\begin{array}{c}\mathrm{r} \mathrm{N}_{2} \mathrm{O}^{\mathrm{c}} \\
\left(\mu \mathrm{g} \mathrm{N}_{2} \mathrm{O}-\mathrm{N} \mathrm{min}^{-1} \mathrm{~g} \mathrm{TSS}^{-1}\right)\end{array}$ & $\begin{array}{l}\mathrm{Y}_{\mathrm{N} 2 \mathrm{O}}{ }^{\mathrm{d}} \\
(\%)\end{array}$ \\
\hline 0.48 & 1.4 & 28 & 0.35 & 0.08 \\
\hline 0.53 & 2.3 & 44 & 0.53 & .0 .11 \\
\hline 1.03 & 7.4 & 155 & 1.79 & 0.33 \\
\hline 1.06 & 8.2 & 175 & 1.65 & 0.28 \\
\hline 1.39 & 16.8 & 414 & 2.50 & 0.70 \\
\hline 1.6 & 17.4 & 402 & 2.42 & 0.62 \\
\hline 3.3 & 19.0 & 779 & 2.75 & 1.17 \\
\hline \multicolumn{5}{|c|}{$\begin{array}{l}{ }^{\mathrm{a}} \mathrm{N}_{2} \mathrm{O}_{\mathrm{MAX}} \text {, maximum concentration of } \mathrm{N}_{2} \mathrm{O} \text { detected in the exhaust gas; }{ }^{\mathrm{b}} \mathrm{N}_{2} \mathrm{O}_{\mathrm{TOT}} \text {, total } \\
\text { amount of } \mathrm{N}_{2} \mathrm{O} \text { in the exhaust gas; }{ }^{\mathrm{c}} \mathrm{rN}_{2} \mathrm{O} \text {, the rate at which the } \mathrm{N}_{2} \mathrm{O} \text { concentration }\end{array}$} \\
\hline
\end{tabular}


Figure 1. Schematic of laboratory scale activated sludge pilot plant (not to scale). 1, feed; 2, buffer; 3, overflow from aeration tank; 4, settling tank, 5, overflow from settling tank; 6 , recycling of biomass; 7 , thermometer; $8, \mathrm{pH}$ probe.

Figure 2. Dissolved oxygen in the aeration tank and dinitrogen oxide concentrations in the exhaust gas from the aeration tank when shock loaded with $1.6 \mathrm{mg} \mathrm{NH}_{3}-\mathrm{N}^{-1} \mathrm{~g} \mathrm{TSS}^{-}$ ${ }^{1} . \Delta=\mathrm{DO}, \square=\mathrm{N}_{2} \mathrm{O}$.

Figure 3. The maximum dinitrogen oxide concentration and rate of increase of the dinitrogen oxide concentration in the exhaust gas from the aeration tank in relation to the level of ammonia shock loading. $\boldsymbol{\Delta}=\mathrm{N}_{2} \mathrm{O}_{\mathrm{MAX}}, \square=\mathrm{rN}_{2} \mathrm{O}$.

Figure 4. Nitrite build up in the aeration tank and dinitrogen oxide in the exhaust gas from the aeration tank: a, ammonia shock load of $1.39 \mathrm{mg} \mathrm{NH}_{3}-\mathrm{N} \mathrm{l}^{-1} \mathrm{~g} \mathrm{TSS}^{-1}$; b,

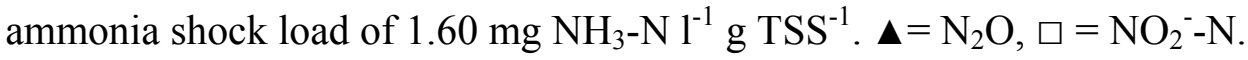

Figure 5. Dissolved oxygen and nitrite profile in the aeration tank and dinitrogen concentration in the exhaust gas from the aeration tank during aeration failure: a, the aeration was turned down from $3.7-0.31 \mathrm{~min}^{-1}$ at time zero; $\mathbf{b}$, the aeration was turned up from $0.3-3.71 \mathrm{~min}^{-1}$ at time 53 minutes. $\square=\mathrm{DO}, \times=\mathrm{N}_{2} \mathrm{O}, \bullet=\mathrm{NO}_{2}^{-}$. 


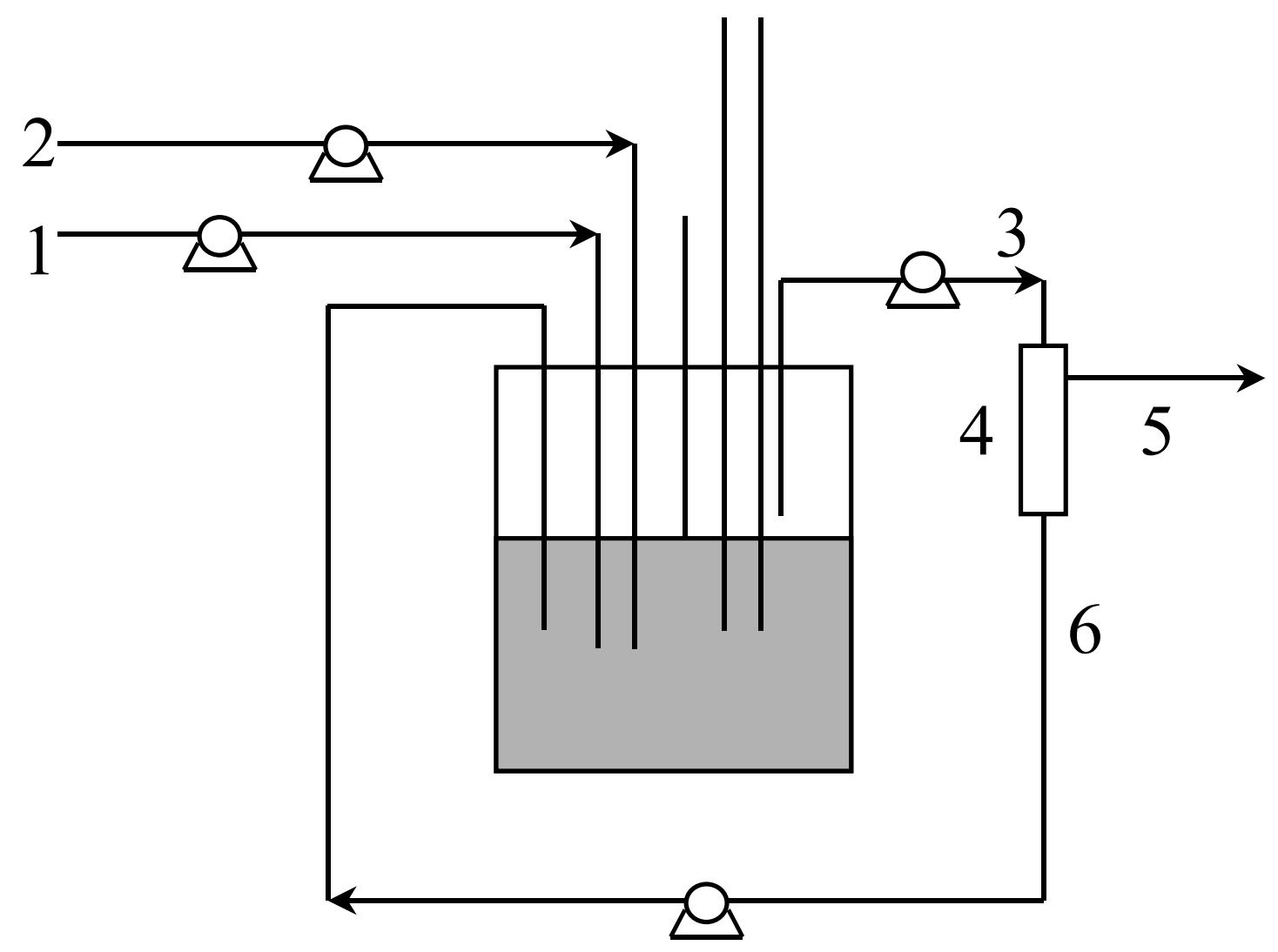




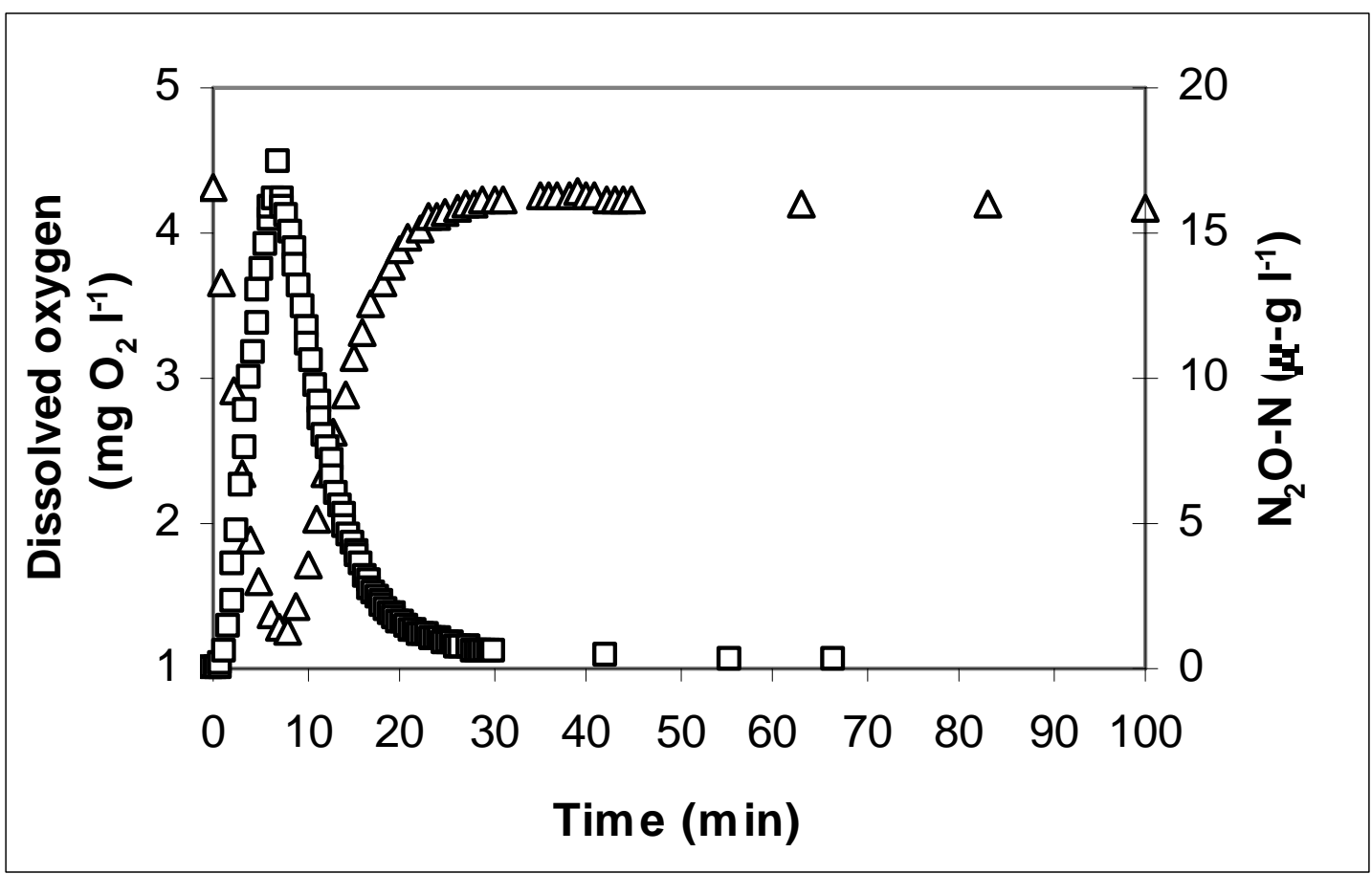




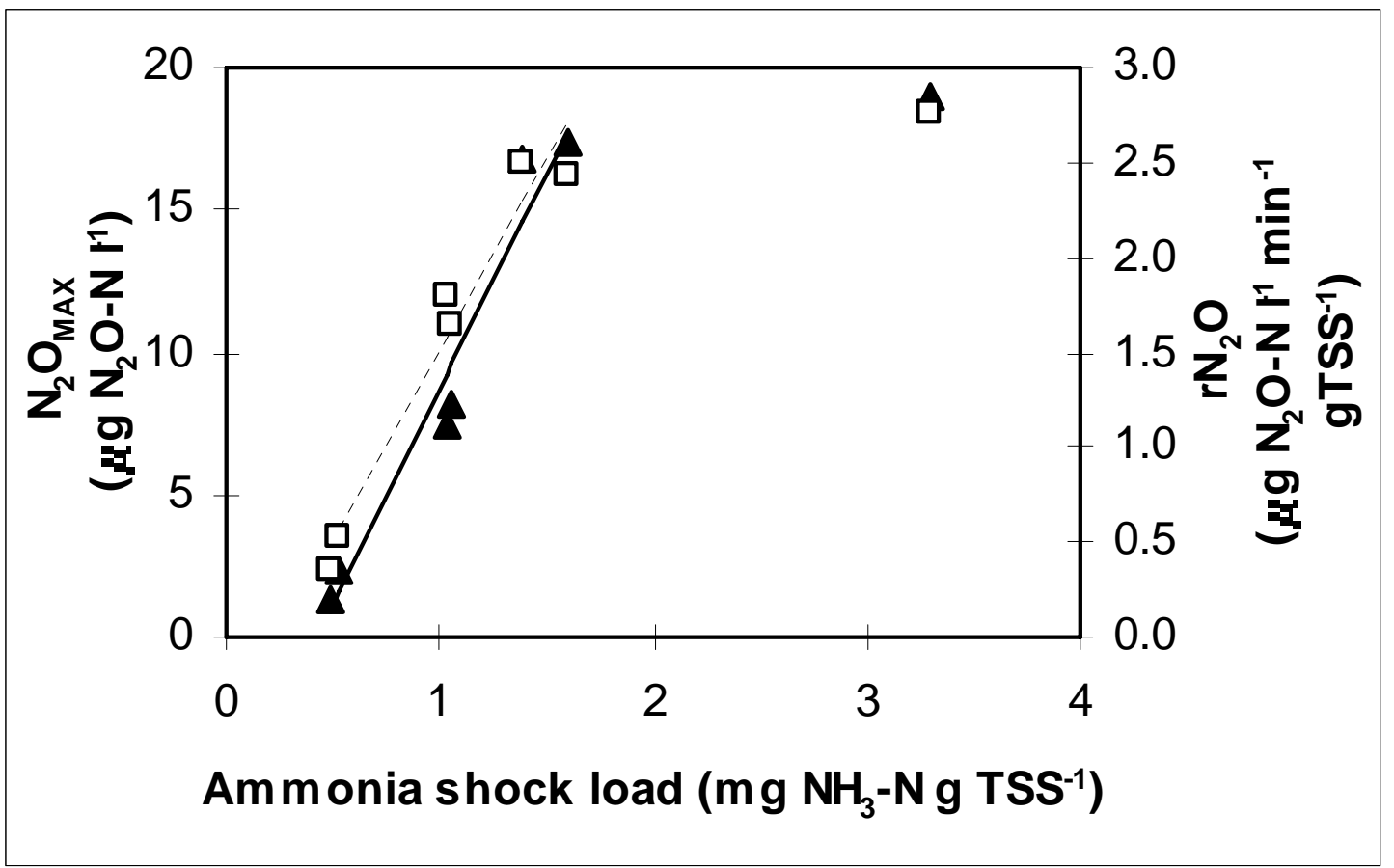



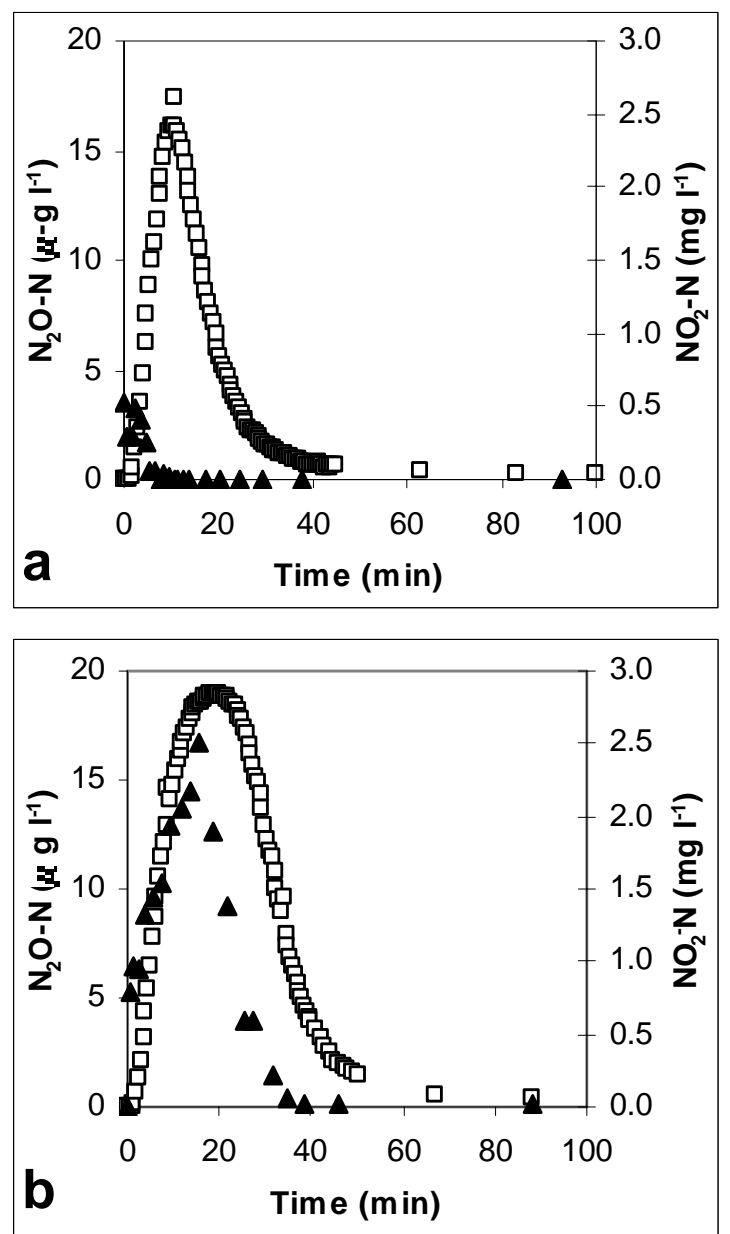

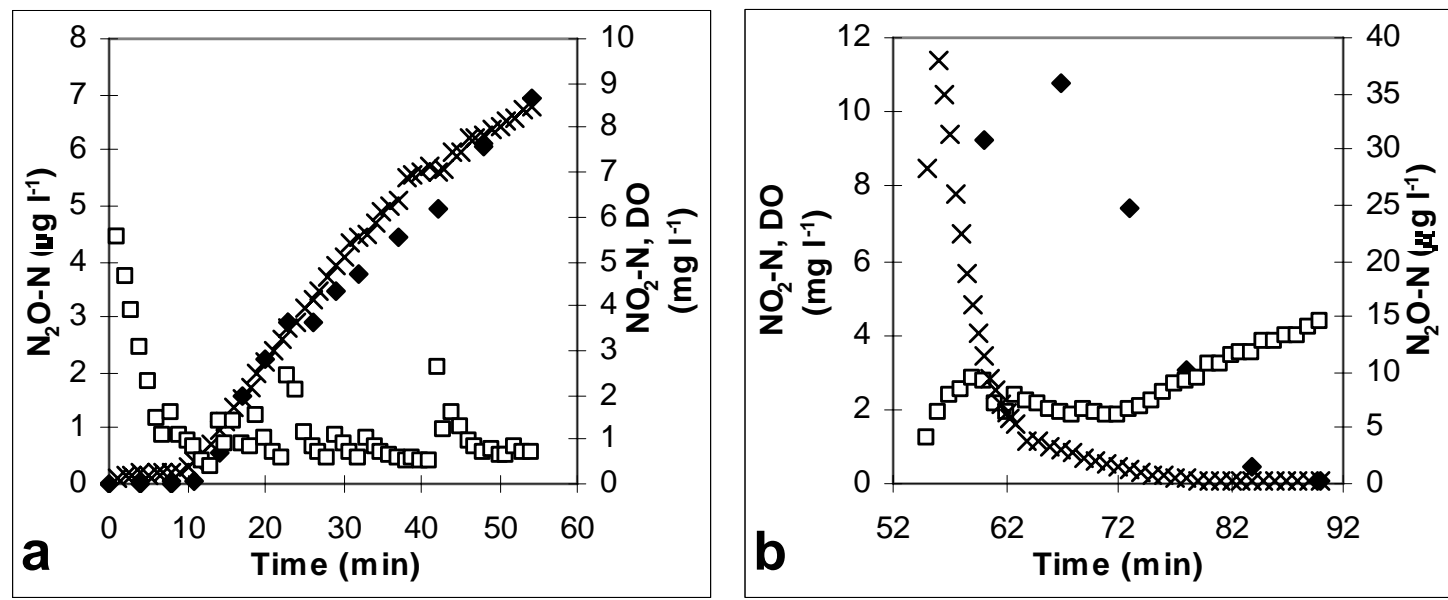